Est.Ag $36(2001) 91-126$

\title{
La Aesthetik de K. F. E. Trahndorff: Ideas para la fundamentación de un romanticismo cristiano
}

\section{1.. Un esteta postergado}

La adversidad del destino ha pesado sobre la figura de Karl Friedrich Eusebius Trahndorff (1762-1863), quien, a pesar de sus notables méritos intelectuales, es hoy en día un pensador completamente olvidado. Fue, sin embargo, un filósofo nada desdeñable, dotado de gran erudición, una enorme capacidad para asimilar creativamente influencias de todo tipo y un poder sistematizador próximo al de Fichte o Schelling. A todo ello habría que añadir dos aspectos que hacen su personalidad aún más atrayente: su gran talento para las cuestiones estéticas, y la firme convicción de que su punto de vista especulativo concordaba con el contenido propio y esencial del Cristianismo, al que concibe de manera muy personal, como una religión en la que la pluralidad de las individualidades concretas, gracias a su despliegue a partir del Uno-Todo, alcanzan cierta inmanencia o contacto espiritual con el Principio puro del monoteísmo ${ }^{1}$.

No se comprende bien por qué un hombre así pasó su vida entera impartiendo docencia en el "Gymnasium Joachimstahl'schen" de Berlín, y aún menos se entiende por qué una obra tan sobresaliente como su Aesthetik, oder Lehre von der Weltanschauung und Kunst -cuyas dos partes se publicaron en 1827-, se ha eclipsado sin dejar rastro alguno en la historia de la filosofía. Mientras que Schelling, Krause, Hegel y Schleiermacher se conformaron con impartir lecciones de estética -que sólo fueron publicadas tras su muerte, con una redacción a veces precaria-, al tiempo que Schopenhauer y Solger permanecían muy lejos de llevar a cabo un tratamiento riguroso de

1 Cf. TrahndorfF, K. F. E., Aesthetik oder Lehre von der Weltanschauung und Kunst, Berlin, Maurerschen Buchhandlung, 1827, II, 391-393. 
los problemas estéticos, Ch. H. Weisse y K. F. E. Trahndorff sí redactaron y publicaron sendos tratados sistemáticos de estética; con todo, el libro de Weisse, System der Aesthetik als Wissenschaft von der Idee der Schönheit, es posterior en tres años a la obra de Trahndorff (pues se publicó en 1830), y, por otra parte, se encuentra dominado por una dialéctica farragosa y estéril que, por fortuna, falta por completo en el pensamiento del filósofo berlinés. Así pues, no parece existir otra justificación para la completa falta de repercusión de la estética trahndorffiana que el hecho de haber sido Weisse profesor universitario en Leipzig, mientras que Trahndorff no pasó de ser un modesto Gymnasiallehrer, al que la egregia personalidad de su contemporáneo Hegel eclipsó completamente.

\section{2.- La metafísica del Poder Absoluto}

La metafísica trahndorffiana es un monismo, próximo al punto de vista del Fichte tardío ${ }^{2}$. Identifica al Uno con el Ser, contraponiéndolo a la pluralidad de la existencia [Dasein] ${ }^{3}$, caracterizada por el devenir y su carácter fenoménico ${ }^{4}$. Pero el Ser mismo, según Trahndorff, es él mismo algo puesto, no originario; el Ser en sentido absoluto es "el Poder Absoluto en sí, un Poder tal que sólo Él es capaz de ponerse a sí mismo" 5. Que el Poder sea significa, según Trahndorff, que puede ponerse a sí mismo ${ }^{6}$. Ahora bien, a la base de cada ponerse a sí mismo -tanto individualmente como en el Absoluto- se encuentra la Voluntad [der Wille], una de cuyas funciones originarias es la capacidad de ponerse a sí misma ${ }^{7}$, surgiendo el Ser en este proceso de auto-posición. En Trahndorff, pues, "Poder" [Können] y "Querer" [Wollen] resultan equivalentes, sin que nuestro autor conceda al Absoluto -cuyo carácter principal es, como acabamos de indicar, la capacidad de ponerse a sí mismo- posibilidad alguna de no poder ponerse a sí mismo, con lo que en su concepción del Absoluto libertad y necesidad se identifican. El término "Poder" no significa en Trahndorff la potencia arbitraria de querer o no

2 Cf. Hartmann, E. von., Aesthetik. Erster historisch-kritischer Theil. Die deutsche Aesthetik seit Kant, Hermann Haacke Verlagsbuchhandlung, Leipzig, 1886, pág. 131.

${ }^{3}$ Cf. TRAHNDORFF, K. F. E., Op. Cit., I 27, 8.

4 Ibidem, I 30, 40.

5 Ibidem, I 30. "das absolute Können in sich, das Können, wie es nur sich selbst in sich kann."

6 Ibidem, I 4.

7 Ibidem, I 175. 
querer, sino que designa un vector que apunta únicamente a la disposición de la Voluntad para llevar a cabo la realización de su contenido ${ }^{8}$.

El Poder Absoluto es la Omnipotencia de la que está dotada la Voluntad Absoluta para su autorrealización; todo poder restringido con capacidad para ponerse a sí mismo no es sino una manifestación de ese Poder Absoluto en el individuo (o, como dice Trahndorff, una manifestación del Poder del Universo $)^{9}$. El Poder Universal se fragmenta reiteradamente en el espacio y en el tiempo, hasta llegar a lo concreto y real, es decir, al individuo, un ser limitado e independiente, dotado de una relativa capacidad para ponerse a sí mismo frente al poder del resto del mundo ${ }^{10}$. Como producto de una potencia, el individuo es un producto necesario de la Naturaleza; pero como ser capaz de ponerse a sí mismo es relativamente independiente o libre ${ }^{11}$. Sin embargo, la libertad no se encuentra en el ser como tal, o en su capacidad para ponerse a sí mismo, sino sólo en el poder que emana de sí mismo frente a otra cosa, en la fuerza de resistencia, en la lucha contra el resto del mundo, y en la capacidad para transformarse; en una palabra, en el querer del individuo [Wollen des Individuums], entendido, no ya como una función originaria primitiva, sino como una función deducida del ser individual12.

El Universo somete a los individuos a una continua presión que, amenazando su vida, les obliga a una "lucha por la existencia", lucha que, no obstante, tiene un aspecto positivo, por cuanto les impulsa a desarrollar su libertad e independencia, sin las cuales el Universo no sería posible (pues su estructura misma, como unidad superior, está condicionada por las actividades de los individuos independientes y de su libertad, todo lo cual permite al Universo existir y expandirse) ${ }^{13}$. Por otra parte, el querer autónomo del individuo, que en principio apunta sólo a la brutal y ruda afirmación y acrecentamiento de la propia existencia, aprende así a acomodarse a la necesidad del Todo, suavizándose la lucha por la existencia mediante las restricciones que impone la mutua limitación y la subordinación al equilibrio de la totalidad ${ }^{14}$. Esta acomodación, autocoerción o autodominio, es algo impuesto por la relativa impotencia que posee el individuo en la lucha por la existencia; se trata de "una autoridad moral represiva que la libertad constituye en su propio alguacil", y que acaba en el momento en que el individuo, con derecho o

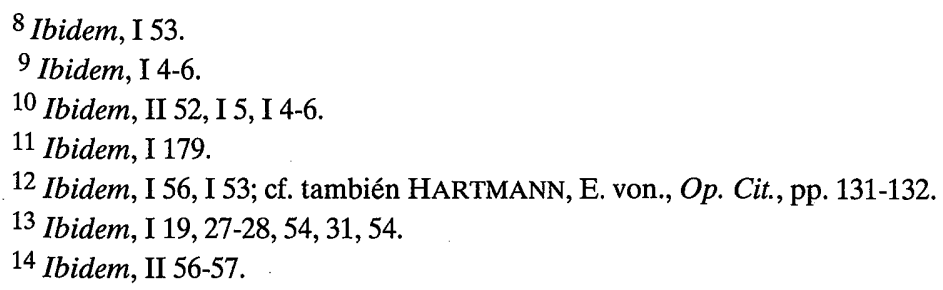


sin él, se considera más fuerte que su contrincante en la lucha por la existencia $^{15}$. Así, el autodominio ético es en este nivel simple consecuencia del forzoso sometimiento a la ley de la necesidad, y desemboca frecuentemente en la humillación de la voluntad del sujeto por parte de otras voluntades. Esto hace que la lucha externa se traslade ahora al interior del individuo, planteándose como un conflicto entre el deber y el querer, que se manifiesta, a nivel anímico, como una permanente fluctuación entre la elevación y la caída moral16.

Para que se produzca finalmente el equilibrio, es necesario que entre en juego otro factor, que palíe la rudeza de la lucha exterior, mantenga la autocoerción dentro de un límite, y transforme el dolor de la humillación en dulce esperanza ${ }^{17}$. Según Trahndorff, la simple fortaleza de la voluntad no puede ser considerada como ideal ético, ya que se autocancela como ideal desde el momento en que, privada del amor, se convierte en un principio hostil y destructivo; por tanto, nada puede llegar a ser un ideal auténtico si no constituye, en última instancia, una unidad con la Fuente Originaria de todas las cosas ${ }^{18}$.

Ahora bien, todo ser individual, incluso en sus grados más bajos, no mantiene meramente una relación negativa u hostil con el Universo, sino también una relación positiva -como se pone claramente de manifiesto en el instinto reproductivo de los animales-; y cuando esa relación positiva o instinto sale a la luz de la libertad recibe el nombre de amor:

"El amor es..., por tanto, la verdadera vida inmediata de la libertad; en él, y a través de él, vive inmediatamente la Forma del Universo. El amor todo lo iguala. Sólo a través de él la fe se convierte en libre vida interior; en él se encuentra, al mismo tiempo, lo más íntimo de la vida espiritual, porque él mismo es la interioridad más íntima del Poder del Universo"19.

El papel que juega el amor en el pensamiento de Trahndorff es primordial: no sólo es el acto por el cual el Uno, proyectado fuera de sí en la indivi-

15 Ibidem, I 127-128. “... eine moralische Zuchtbehörde, welche die Freiheit zu ihrem Büttel macht".

16 Ibidem, I 148-149.

17 Ibidem, I 149-159.

18 Ibidem, I 128.

19 Ibidem, I 150-151. "Die Liebe ist also auch das wahre unmittelbare Leben der Freiheit; in ihr und durch sie lebt unmittelbar die Form des Universums. Sie gleicht alles aus. Der Glaube wird erst durch sie ein freies inneres Leben; in ihr ist zugleich das innerste des geistigen Lebens, weil sie selbst das Innerste ist in dem Können des Universums." 
duación, retorna de nuevo a sí mismo a través de la fe (que nos pone en contacto con el Ser como Principio puro del monoteísmo $)^{20}$, sino que también es el elemento fundamental en su concepción estética del mundo y del arte; en efecto, el amor se encuentra a la raíz de todas las actividades espirituales en las que se trata de una captación de la Unidad del Universo, y, desde el momento en que una vida consagrada al arte se presenta, ante todo, como una tendencia a alcanzar la fusión plena con dicha Unidad, estamos autorizados para definirla como una vida que se desenvuelve en el medium universal del amor ${ }^{21}$.

El problema que se plantea de inmediato es el de cómo se produce el tránsito desde la Voluntad Originaria, y el Ser Único por ella producido, a la multiplicidad de la existencia que compone el Universo. Según Trahndorff, puesto que la pluralidad de la existencia ha surgido de la capacidad de ponerse a sí mismo del Ser Único, parece claro que la realización del Poder (o del querer capaz de realización) debe implicar, a su vez, una relación entre el Ser Único y la existencia múltiple, relación a la que Trahndorff denomina Forma de la existencia o Forma del Universo. La forma es la condición del aparecer 22 ; ninguna existencia es posible sin ella, de manera que una existencia carente de forma es un concepto abstracto carente de significado ${ }^{23}$; no obstante, la forma es sólamente la condición del fenómeno, es decir, sólo es forma de la existencia, pero en el Ser mismo no es aún real, sino que constituye la condición de posibilidad de la existencia, por lo que en el Ser aparece como Idea. Esto significa que la Forma del Universo, o la relación del Ser Único con la existencia múltiple debe preexistir en el Ser como Idea, antes de ser realizada por el Poder; así se explica que en ocasiones Trahndorff hable de la "Idea de la Forma del Universo" 24 , entendiendo por "Idea" no una construcción del espíritu humano, sino la Idea de la Forma del Mundo, que se encuentra situada más allá de toda conceptualización humana en las profundidades de la Divinidad25. Puesto que el Ser sólo llega a ser Dios por contraposición al mundo, Dios, como aquel Ser que se relaciona con la existencia, pero no se resuelve en el fenómeno, puede considerarse como la Idea Suprema de la Forma del Mundo. Así pues, la Forma del

${ }^{20}$ Ibidem, I 151. "In dem Glauben durch die Liebe ist gegeben das Sein, als ein rein monotheistisches Prinzip."

21 Cf. HARTMANn, E. von., Op.cit., pág. 133.

22 Cf. TRAHNDORFF, K. F. E., Op. cit., I 21.

23 Ibidem, I 8, 20 - 21.

24 Ibidem, II 73.

25 Ibidem, I 96. 
Universo existente no puede ser nada más que la Idea de la Forma del Mundo, inmanente al Poder del Universo, y realizada a través de ese Poder, o dicho de otro modo: la forma real inmanente al mundo es de hecho un fenómeno que se sigue de la realización de la Idea de la Forma del Mundo en un determinado ser ${ }^{26}$.

Antes de pasar adelante, es menester entender bien. el concepto trahndorffiano de "Forma del Mundo" [Weltform]. Se trata de un concepto que, históricamente, remite al universo ideal de Schelling como "forma de las formas", pero que se identifica más bien con la Idea hegeliana. No tiene nada que ver con el concepto abstracto de "forma" utilizado por los estetas formalistas, ni tampoco debe confundirse con una forma fenoménica sensible concreta. E. von Hartmann cree que Trahndorff escogió esta expresión debido a que deseaba eludir cualquier posible confusión de la Idea absoluta suprasensible, como factor determinante del mundo, con las ideas abstractas presentes en la mente humana, o con los ideales estéticos intuitivamente sensibles; sin embargo, la ambigüedad del término hace que una lectura superficial de los textos de Trahndorff sugiera una interpretación simplemente formalista de los mismos.

\section{3.- Los grados de concepción del mundo y el amor}

"La Humanidad vive tal como concibe el mundo" 27; partiendo de este principio, Trahndorff lleva a cabo una investigación gnoseológica en torno al concepto del concebir [Erfassen] en general, deduciéndolo, como no podía ser menos, del concepto de "poder", es decir, de la fuerza de autoafirmación del individuo frente a las afecciones que pueda sufrir por parte del mundo entorno.

Dado que el individuo afectado no es un mero poder del Universo, como cualquier otro individuo inanimado, sino que también es un ser relativamente independiente, en el que el poder del Universo es capaz de ponerse a sí mismo, también reside en él la capacidad de oponerse a cualquier afección particular ${ }^{28}$. En dicho oponerse se despliega, al mismo tiempo, un comprender [Verstehen], es decir, la capacidad de concebir algo concreto a través del contacto que se produce entre el mundo y el individo ${ }^{29}$; en todos los gra-

\footnotetext{
26 Cf. HARTMANN, E. von., Op. cit., pág. 135.

27 TRAHNDORFF, K. F. E., Op. cit., II 327. "So wie die Menschheit die Welt erfasst, so lebt sie."

28 Ibidem, I 36.

${ }^{29}$ Ibidem, I 35, 37.
} 
dos del concebir encontramos, por consiguiente, una actividad intelectual sin la cual no serían posibles ni el sentimiento ni la intuición. En cualquier caso, la expresión "comprender" no designa a este nivel una argumentación deductiva de tipo discursivo, en la que existiese una conciencia plena de las premisas, de las conexiones lógicas y de la secuencia de los razonamientos, sino que se trata "de un comprender realmente originario, un juicio inmediato, es decir, una inferencia de la que sólo la conclusión nos llega a la conciencia"30.

a) El primer grado del concebir es el sentimiento [das Gefühl]; en este nivel el yo es potencia de sí mismo y se concibe a sí mismo, no contra el mundo y en su afección por él'11, pues el yo es demasiado débil al principio como para desarrollar activamente su poder, por lo que aún permanece en la mera sensación, en la que todavía no se concibe a sí mismo como existente y afectado; por eso la sensación no puede considerarse aún un "concebir" propiamente dicho, sino más bien una mera "alteración inconsciente" [bewusstloses Anderswerden ${ }^{32}$. Al hacerse más intensa la sensación -como cuando, por ejemplo, el individuo es afectado por un dolor-, la sensación se eleva al rango de sentimiento, y se hace necesaria la referencia a un yo. $\mathrm{El}$ yo es consciente a este nivel, tanto de la determinación de las sensaciones y de los sentimientos, como de su mutua diferencia, pero aún no lo es del yo como ser, dado que, de momento, sólo se capta como existente en y con la afección misma ${ }^{33}$.

b) El segundo grado del concebir es la intuición [die Anschauung]. En ella se concibe el mundo según su forma de afectar al yo de una determinada manera, mientras que éste último, contrapuesto a la Forma del Mundo que le influye, parece ocultarse mediante una ilusión óptica tras la intuición del objeto $^{34}$. De hecho, en la intuición está implícitamente concebido el yo, al igual que en el sentimiento el mundo entorno que afecta al individuo, pero la ilusión mantiene toda su intensidad debido a su carácter necesario e inevitable ${ }^{35}$. En los momentos en que la intuición es muy vivaz, abstraemos por completo incluso la existencia de lo intuido, abriéndonos por completo a la intuición de la forma (como aquello gracias a lo cual lo intuido se encuentra

30 Ibidem, I 37-38. "...so wird also das Verstehen in der Anschauung, bloss als Anschauung, ebenfalls wieder ein unmittelbares Urtheil, ein Schluss, von welchem aber nur die Conclusion zum Bewusstsein kommt."

31 Ibidem, I 5.

32 Ibidem, I 7.

33 Ibidem, I 28, 37.

34 Ibidem, I 22-23, 38.

35 Ibidem, I 23. 
ahí presente ante nosotros), hasta el punto de que debemos hacer un esfuerzo por recordar nuestra propia existencia y hacernos conscientes de la realidad de lo intuido ${ }^{36}$.

c) El tercer grado del concebir a través de la actividad del entendimiento es el pensar o la reflexión [die Reflexion] ${ }^{37}$. El concebir del yo en función de la existencia externa determinada, y el concebir del mundo según su forma de afectar, se encuentran separados en el sentimiento y la intuición, pero deben llegar a una síntesis; allí donde permanecen sin separarse, como sucede en los animales, resulta imposible ascender a un grado superior, e igual sucede si ambos miembros de la contraposición dialéctica permanecen mutuamente aislados ${ }^{38}$. Lo que les une es "el concebir del concebir" [das Erfassen des Erfassens], que mantiene separados al sentimiento y a la intuición, siendo consciente de la contradicción que media entre el yo y el mundo (mientras que en el primer grado sólo se diferenciaron los sentimientos y en el segundo sólo las intuiciones entre sí).

El problema radica ahora en que la intuición se limita a acumular imágenes hasta el infinito, sin alcanzar con ello una unidad completa ${ }^{39}$, mientras que la reflexión, por su parte, combina discursivamente series de pensamientos, sin sobrepasar nunca el ámbito de los fenómenos ni alcanzar jamás lo Absoluto, el Ser ${ }^{40}$. Es verdad que, tanto en el grado del sentimiento, como en los de la intuición y la reflexión, se encuentra una relación implícita de lo múltiple a la unidad, relación que es de tipo formal; pero tal unidad es sólo relativa, es decir, cada multiplicidad remite a una unidad formal finita relativamente superior, y así sucesivamente, hasta culminar en la última y más elevada unidad, la Forma del Universo ${ }^{41}$, la cual sólo podría llegar a ser intuida si el Universo pudiese ser intuido como totalidad unitaria carente de contradicciones, algo que resulta imposible, dada la contraposición que media entre el mundo y el yo. Así pues, tanto las limitaciones de la intuición, como el infinito progreso de la reflexión se ven incapacitados para conducirnos a la Forma del Universo como totalidad unitaria y al Ser Único que se encuentra a su base; por ello debe pasarse a un nuevo grado del concebir ${ }^{42}$.

\footnotetext{
36 Como fenómeno subjetivo, este desligamiento de lo intuido de toda realidad objetiva es muy importante, ya que constituye el fundamento psicológico que más tarde hará posible la apariencia estética: Cf. HARTMANN, E. von., Op. cit., pág. 137.

37 TRAHNDORFF, K. F. E., Op. cit., I 8, 38.

38 Ibidem, I 38.

39 Ibidem, I 34.

40 Ibidem, I 40-41.

41 Ibidem, I 75.

42 Ibidem, I 76, 23-24, 41.
} 
d) Este cuarto grado es la noción [die Ahnung] ${ }^{43}$, el grado máximo de intelectualidad, es decir, de la actividad del entendimiento. Sólo en él todo lo múltiple es referido a la última y más elevada unidad; pero Trahndorff cree que incluso este nivel de aprehensión del Ser es extremadamente indeterminado, y sólo permite caracterizarlo, todo lo más, como "unidad" e "inmutabilidad" frente a la multiplicidad cambiante de la existencia. Y puesto que, a juicio del filósofo berlinés, nuestra mente exige la noción un Ser explícito eny-para-sí, es decir, abstraído de los fenómenos, que pueda ser captado por ella como algo unitario y permanente (lo que, como estamos viendo, no parece posible partiendo de la existencia), se requiere otro camino que permita acceder al Ser-en-y-para-sí como Fuente de Vida de la que manan toda existencia y todo devenir ${ }^{44}$.

Ese nuevo camino viene marcado, según Trahndorff, por la voluntad del individuo, o, como él la denomina, el poder con capacidad de realización ${ }^{45}$; el querer o poder del individuo, que en sí mismo no es sino el Poder del Universo en él, debe sacar de sí mismo, o producir a priori, la Forma del Universo, bien como un querer y actuar éticos permanentemente renovados, bien como obra artística permanente ${ }^{46}$. Ahora bien, lo éticamente bueno está él mismo implicado en el proceso del devenir, y la obra artística, al ser imagen, sólo ofrece el Ser implícitamente en la representación; por ello el Ser producido a priori, a la vez permanente y unitario, sólo alcanza su expresión perfecta bajo la forma del ideal ético, que primero se manifiesta bajo la forma inadecuada de la ley, pero más tarde lo hace en la forma realmente adecuada del amor ${ }^{47}$, forma superior del ideal ético, que debe guiar el cumplimiento de la ley moral.

$\mathrm{El}$ anhelo, según Trahndorff, es la forma indeterminada primaria a través de la cual se manifiesta el impulso apriorístico hacia el Ser Único; en sí mismo no es sino "la vida del amor, orientada a la Unidad, a lo Inmutable y Eterno, que se siente impedida, y se capta a sí misma a través de dicho impedi-

43 Ibidem, I 42.

44 Ibidem, I 43-44, 139-140, 137-138. Este punto de vista se contrapone absolutamente a la aprehensión del Ser tal como la entiende Eduard von Hartmann; para éste último el camino inductivo de la especulación científica permite ganar un concepto del Ser completamente determinado (aun cuando sólo dado implícitamente en la existencia y en el devenir). La diferencia de perspectivas en torno a la aprehensión del Ser Supremo depende del distinto punto de vista adoptado por ambos pensadores: Trahndorff parte de un teísmo de raíz cristiana; E. von Hartmann de una suerte de panteísmo inmanentista.

45 Ibidem, I 47.

46 Ibidem, I 48-51.

47 Ibidem, I 144-148. 
mento"48; la fe, por su parte, entendida como una concepción del Universo en la que éste aparece como unidad íntimamente subordinada a un Único Principio, fuera del cual nada existe, surge a través del inextinguible anhelo de amor ocasionado por la contradicción que media entre el Ser Único y el individuo ${ }^{49}$. En ambos sentimientos se hace patente que sólo el amor constituye la más íntima relación de la libertad con la Forma del Universo; sólo él permite alcanzar el sentimiento de la unidad esencial y plena del Uno-Todo con el individuo, y, por consiguiente, sólo él supone la plena satisfacción del anhelo, la fe y la ley moral ${ }^{50}$.

\section{4.- Relaciones entre política, ciencia, religión y arte}

Trahndorff separa escrupulosamente los dominios de la política, la ciencia, la religión y el arte. La política es la unión forzada por la necesidad que supone el deseo de supervivencia, y su principal cometido es definir los límites hasta los que puede expandirse dicho deseo, sin perjuicio de los intereses

48 Ibidem, I 151: "[Die Sehnsucht ist] das sich gehemmt fühlende und durch diese Hemmung sich selbst erfassende Leben der Liebe, gerichtet auf eine Einheit, auf ein Unwandelbares und Ewiges."

49 Ibidem, I 147-148.

50 Ibidem, I 148-151, 174. Trahndorff cree, por otra parte, que sólo una fe enraizada en el amor puede ser una fe verdaderamente monoteísta, mientras que una fe basada en el temor conduce inevitablemente al fatalismo y al politeísmo (cf. Ibidem, I 153-168). E. von Hartmann, auténtico "descubridor" del pensamiento trahndorffiano, discrepa también aquí con las tesis de nuestro autor: afirma que, por verdadera y bella que pueda ser esta concepción del amor como sentimiento del individuo que condiciona su posición respecto del Universo, se trata de una concepción que pasa por alto que el amor sólo es un reflejo sentimental subjetivo de la forma absoluta del mundo y de su acción sobre el individuo, y no esa forma objetiva misma; y menos aún se trata de algo que se encuentre en seno del fundamento absoluto del Universo junto, o antes, de la emanación de la forma del mundo. Este reflejo sentimental subjetivo se proyecta luego objetivamente, según Hartmann, con lo que parece dar la sensación de que se captaría inmediatamente la Esencia Cósmica misma en su unidad y permanencia absolutas. A juicio de von Hartmann, es un error parecido al que cometió A. Schopenhauer, que se imaginaba haber captado la cosa en sí en el querer empírico del individuo concreto, cuando en realidad sólo se las había con un simple fenómeno psicológico. Sin embargo, cree Hartmann que el error de Trahndorff apenas tiene consecuencias para su estética, ya que en la concepción y producción estéticas el Ser Absoluto no puede ser captado y representado explícitamente, sino sólo implícitamente como algo inmanente al fenómeno, de manera que aquí los sentimientos subjetivos sólo pueden y deben entenderse como representaciones surrogadas del Ser Absoluto o de la Forma del Universo. Por eso, en la concepción estética -al contrario que sucede en el amor puro- no nos figuramos estar en presencia del Ser Permanente mismo, sino que nos vemos siempre remitidos a inferirlo a partir de la configuración individual de lo múltiple, como fuente o principio vital de la misma (cf. Op. cit., pp. 130-140). 
espirituales más profundos 51 . La ciencia es la traída a la conciencia de la Forma del Universo y de la totalidad de las conexiones internas de los fenómenos que lo componen, es decir, la concepción de la Forma del Mundo por la forma del yo ${ }^{52}$. La religión es el despliegue inmediato de la vida del amor en la dirección del anhelo, hasta la efusión total del ánimo, como sucede en el éxtasis del profeta y del visionario; es la apertura del poder limitado del individuo al Poder Absoluto, es decir, la apertura de la voluntad individual a una Voluntad Universal, por lo que supone la última y más elevada meta a la que puede tender todo el desarrollo humano ${ }^{53}$. El arte, por último, es el autoconcebirse a sí mismo del amor a través del puro concebir la Forma del Universo por mor de sí misma ${ }^{54}$.

La política, la ciencia, la religión y el arte constituyen en la perspectiva de Trahndorff, un todo indisoluble, por lo que todo postergamiento o abandono de una de estas direcciones interconectadas de la vida espiritual tiene consecuencias negativas para las otras. Si se excluye al pueblo de la política, dejándole abiertas las restantes direcciones, la totalidad se descompone, se desvirtúa el amor y se hace imposible que el ser humano capte el principio más elevado del mismo; los hombres entonces consideran el deseo de existir como lo más elevado y el arte y la ciencia quedan rebajados a meros adornos lujosos de la existencia ${ }^{55}$. Si se separa a la religión de su conexión con el resto de la vida espiritual, el individuo queda alienado de todos los demás intereses espirituales y se sumerge en lo Absoluto, olvidándose del deseo de existencia del yo; si el sujeto se entrega de lleno a la concepción de la forma puramente por mor de sí misma y sin fin práctico alguno, puede caer en un burdo utilitarismo; por último, si se busca independizar al arte, desvinculándolo de la religión, o con ánimo de sustituirla (como sucede en el "arte por el arte"), degenera en un mero juego de formas vacías, convirtiéndose en un frívolo artículo de lujo; por eso afirma Trahndorff que "el arte se mantiene $y$ sucumbe con la religión, al igual que debería suprimirse por completo, una vez alcanzado el más elevado cumplimiento de la vida religiosa"56. Esta visión global de Trahndorff de una totalidad unitaria que abarca toda la vida espiritual, en la que no puede prescindirse de ninguna dirección de la misma,

51 Ibidem, II 73.

52 Ibidem, II 73, I 9-10

53 Ibidem, II 6-7; I 57, 59, 60.

54 Ibidem, I 59.

55 Ibidem, II 75.

56 Ibidem I 184. "Mit der Religion steht und fällt die Kunst, eben so wie sie ganz aufhören müsste in der höchsten Vollendung des religiösen Lebens" 
y en la que cualquier avance de cada una de sus vertientes se encuentra condicionado por el progreso de las restantes, parece encontrarse muy por encima de la de los otros estetas de la época, que, siguiendo el método dialéctico, trataban de presentar una ordenacion jerárquica de las mismas ${ }^{57}$.

\section{5.- La cosmovisión estética}

La actividad espiritual estética consiste, como acabamos de indicar, en un concebir la Forma del Mundo, pudiendo ser determinada por el fin que tal concebir persigue. Todo concebir la Forma del Mundo por parte de un individuo se hace por mor del individuo que concibe, por mor del mundo concebido, o se trata, por último, de un concebir que no persigue ni una cosa ni otra, sino que se presenta sólo como puro fin en sí mismo, un "concebir por concebir". Un concebir el mundo puesto al servicio del individuo corresponde al ámbito de la habilidad vital y de la investigación que se realiza con vistas a obtener un provecho; un concebir el mundo puesto al servicio del mundo se traduce en el trabajo y actuar ético; finalmente el concebir el mundo por el mero hecho de concebirlo conduce a la cosmovisión estética:

"El concebir encierra una triplicidad, a saber: 1) concebir el mundo por mor del que lo concibe (el individuo), 2) concebir el mundo por mor de lo concebido (el mundo), y 3) el concebir el mundo por mor del concebir mismo. En el primer caso, el momento principal radica en la Verdad y el Saber; en el segundo, en el Bien y el Hacer; en el tercero, en lo Bello, o en el puro concebir por sí misma la Forma del Universo ${ }^{58}$.

Trahndorff considera que el "concebir por concebir" estético se basa exclusivamente en la intución, la aísthesis de los antiguos griegos ${ }^{59}$, que, gracias a la fantasía y al principio de individuación (el espacio-tiempo), se constituye como un todo concluso y cerrado, una imagen ${ }^{60}$, en la que la Forma del Universo se manifiesta ante nuestra conciencia de forma concreta.

57 Piénsese, por ejemplo, en Schelling o Hegel: Cf. HARTMANN, E. von., Op. cit., pág. 141.

58 TRAHNDORFF, K. F. E., Op. cit., I 15. “Eben so fanden wir der Erfassen für Etwas als ein Dreifaches, nämlich als Erfassen der Welt: 1) für das Erfassende (für das Individuum), 2) für das Zu-Erfassende (die Welt) und 3) für das Erfassen selbst. In dem Ersten liegt als Hauptmoment die Wahrheit und das Wissen, im Zweiten das Gute und das Thun, im Dritten das Schöne oder das reine Erfassen der Form des Universums für sich."

59 Ibidem, II 443.

60 Ibidem, I 27, II 34, 53. 
Cada imagen, por su parte, constituye un miembro referido a una imagen superior, abarcando, por su parte, como totalidad unitaria, un conjunto de imágenes subordinadas a ella; por ello, el reino de la intuición es un reino de imágenes encadenadas, cuya cúspide sería la Imagen del Universo ${ }^{61}$. Cada imagen individual aislada incluye en sí la Forma del Universo, en la medida en que se refiere a una unidad superior, y, en última instancia, a la totalidad unitaria del Universo ${ }^{62}$; es lo que Trahndorff denomina el "carácter microcósmico" de la imagen, carácter que lleva a esa imagen en cuestión a representar en mayor o menor medida la "Idea macrocósmica".

La Naturaleza está constituida por una totalidad de imágenes, de las que algunas pueden ser extraídas del flujo del devenir mediante la simple contemplación estética, mientras otras, las imágenes propiamente artísticas, son las que ya han sido extraídas permanentemente de dicho flujo por los artistas 63 ; estas imágenes se contraponen (bajo la forma de obras de arte) al conjunto de la Naturaleza, y como creaciones reales que expresan para el concebir la Forma del Universo, tienen la misma pretensión de duración e inmortalidad que posee la Naturaleza en su conjunto ${ }^{64}$.

En el fulgor de la inspiración, se despliega de forma casi inconsciente ante el espíritu del artista la Forma del Universo, en imágenes microcósmicas internamente cerradas. Ahora bien, dado que es el mismo Poder del Universo el que impera tanto en la Naturaleza como en el artista, debe existir una concordancia entre la imagen natural y la imagen artística, tanto en lo que concierne a la existencia y al devenir fenoménicos, como en lo que se refiere al Ser, por lo que en el verdadero arte existe siempre una perfecta concordancia entre naturalidad e idealidad.

El artista crea a priori, trasladándose y abriéndose por completo al Poder Absolutamente Originario del Universo; pero su actitud no es la del místico religioso, que se limita a permanecer en el seno de ese Poder, sumido en una inerte quietud, sino que pretende partir del Centro fundamental de lo real para poner en relación su propio poder con el Poder total del Universo; así consigue cooperar, en cierta medida, con el Creador Divino, porque el Poder Absoluto, es decir, el Poder que determina la forma de toda existencia, le es inmanente como individuo, y su propia fuerza creadora no es sino un eco del Poder Absoluto que actúa a través de él65.

\footnotetext{
${ }^{61}$ Ibidem, I 90, 27.

62 Ibidem, I 68, 90.

63 Ibidem, II 15.

${ }^{64}$ Ibidem, II 16, 37.

65 Ibidem, I 50, 57.
} 


\section{6.- Genio y talento artísticos}

La imagen microcósmica del Universo intuida por el artista no debe permanecer simplemente en su interior; lo que éste ha proyectado primeramente para sí mismo, debe llegar a ser un bien común concebido por todos; de ahí que dicha imagen deba exteriorizarse como obra mediante una acción creadora efectiva ${ }^{66}$.

Como hemos indicado anteriormente 67 , tanto el Universo en general, como la vida humana en particular, están dominados por la violencia de la necesidad, que tiende a utilizar para sí misma todo lo superior; por ello, apenas es concebible cómo podría el arte liberarse de ponerse él también al servicio de las múltiples necesidades vitales, a no ser que suceda un milagro, y baje una divinidad del Cielo para salvarle. Pero ese milagro sucede realmente, y lo que salva al arte es el genio, en cuyo interior, mediante una revelación de lo alto, nace una vida superior que nunca podría haber surgido a partir del simple desarrollo natural. Sólo una serie de revelaciones geniales de este tipo han permitido alcanzar al arte a lo largo de la historia sus momentos de máximo esplendor68. Para el arte puesto al servicio de la necesidad, basta el talento, es decir, cierta disposición para superar determinadas dificultades técnicas; también basta el talento para repetir las revelaciones realizadas por el genio y proseguir los caminos que éste ha abierto. Con ello, el talento artístico asegura su fortuna, porque sigue la línea del gusto marcada por el público. El genio, por el contrario, no es un eslabón más de la cadena de artistas que desemboca en el presente, sino que es el punto de arranque originario de un nuevo principio artístico, lo que hace que suela entrar en contradicción con el mundo preexistente. Si encuentra reconocimiento público, ello se debe, por lo general, no al verdadero contenido de belleza que posean sus obras, sino al carácter novedoso de las mismas, que estimula la curiosidad de un público dificilmente preparado para adivinar en qué consiste el verdadero mérito de su labor. Por esta razón, su auténtico triunfo -del que, a pesar de todo, está seguro- casi nunca llega a presenciarlo él mismo ${ }^{69}$.

El mero talento se las arregla con una concepción del Universo que le viene dada y que, en el fondo, le es extrínseca; el genio, por su parte, no puede prescindir, desde luego, del requisito previo de poseer talento, pues

\footnotetext{
${ }^{66}$ Ibidem, I 180, II 52-53, 76-77.

${ }^{67} \mathrm{Cf}$. supra, § 2.

68 Ibidem, I 186.

${ }^{69}$ Ibidem, I 188-189.
} 
sería una inconsecuencia de la naturaleza que la fuerza interna originaria, que constituye su disposición fundamental, no fuese capaz de poseer al menos la disposición técnica para la creación artística. Asimismo, tanto el mero talento como incluso alguien que carece de él, pueden gozar de un momento pasajero de inspiración, debido a una fuerte estimulación; pero en el genio tal inspiración, dirigida a lo más elevado, es un rasgo fundamental de su ser que, por naturaleza, le impide caer en la superficialidad, y estimula todas sus fuerzas hacia el logro de la meta suprema ${ }^{70}$.

La inspiración del genio, dirigida a lo más elevado, se fundamenta en una sensibilidad que tiende hacia la Forma del Universo, pero no en grado mínimo, como sucede en la vida cotidiana, sino en su grado máximo ${ }^{71}$. Tal inspiración no es otra cosa que el amor en su impulso para concebirse a sí mismo, y que, como anhelo insaciable, constituye el primer resorte y la meta última del sentir y crear artísticos. En el concebir el amor como la Forma más elevada del Universo, la vida del amor se concibe y concuerda consigo misma y, dotada de una capacidad de dominio superior, somete a la intuición, burlándose desde su infinitud de toda construcción que se ajuste a simples reglas ${ }^{72}$; por eso la actividad del genio se asemeja a la del niño, el cual se encuentra liberado de las preocupaciones vitales, y se entrega felizmente en sus juegos al contacto amoroso con la forma pura:

"El sentimiento y la vida interna del artista verdaderamente grande no es otro que el de un niño feliz. El genio es un niño durante toda su vida [...]. Por eso el arte sólo puede prosperar en tal estado de ingenuidad, y allí donde ésta se ha perdido, no pueden sustituirla ni las Escuelas de Arte, ni Academias, ni viajes a Roma. Dejad al genio, ese muchacho alado, jugar con sus sueños dorados y creará nuevos mundos; no le molestéis; iprotegedle, más bien, con amor paternal! Ah, en verdad os digo que, si no llegáis a ser como niños, no podréis alcanzar el Reino Celestial del Arte."73.

\footnotetext{
70 Ibidem, 1187.

71 Ibidem, I 186.

72 Ibidem, II 3-4, 428

73 Ibidem, I 194. "Aber das Gefühl und innere Leben des wahren grossen Künstlers ist kein anderes, als das des glücklichen Kindes. Er ist ein Kind sein ganzes Leben hindurch. Daher liegt schon in den Kinderspielen des ganze Leben des Künstlergenies, und er bewahrt es bis an den Tod. Daher kann nur in dieser Kindlichkeit die Kunst gedehien, und, wo sie verloren ist, können nicht Kunstschulen, nicht Akademien und Reisen nach Rom den Verlust ersetzen. Lasst nur den Genius, den geflügeten Knaben, sich heraufspielen in seinen goldenen Träumen, und er wird neue Welten erschaffen; aber stört ihn nicht, sondern schirmt ihn mit elterliche Liebe! Ach, so ihr nicht werdet wie Kindlein, könnet ihr auch nicht in das Himmelreich der Kunst gelangen."
} 
La relación entre genio y talento artístico nos permite aclarar la definición trahndorffiana del arte como vida del amor que se concibe a sí mismo. Si partimos de la definición del amor como relación sentimental del individuo hacia la Unidad que se encuentra a la base del mundo, y de la definición de la Idea, o Forma del Universo, como relación o vínculo entre el Ser Unitario y la multiplicidad de la existencia, es indiscutible que también la inspiración artística del genio constituye la actualización del amor al Uno Supremo y a su expresión como Forma del Universo ${ }^{74}$; asimismo, resulta innegable que esta profunda vida amorosa es también la única y mas profunda fuente de la creación artística, tal como se expresa en la profunda religiosidad de los antiguos maestros, de manera que no puede ser sustituida por ningún estudio, saber o técnica ${ }^{75}$.

Por otra parte, si el ideal es la relación de la obra artística con el Ser o esencia del mundo, concibiéndose en él la verdadera Forma del Universo en forma intuitiva, es claro que el amor, que tiende a concebir la Forma del Universo en su verdad, sólo puede encontrar satisfacción en el ámbito estético en la concepción del ideal ${ }^{76}$. Al igual que el genio crea partiendo del anhelo e inspiración que suscita en él el amor, también en el contemplador es el amor que se concibe a sí mismo lo que es despertado por el encanto que ejerce la manifestación del ideal. El entusiasmo por el ideal contemplado purifica el interior del ser humano, lo ennoblece y eleva, liberándole de la necesidad y poniéndole en relación con la verdadera Forma del Universo; es así como supera cualquier escisión impuesta por la realidad, y coincide consigo mismo en la órbita de un auténtico círculo mágico ${ }^{77}$.

La inusual fuerza de espíritu que habita en el genio debe ser despertada también en las naturalezas menos sensibles, y esto se logra a través de la objetivación de la imagen artística que en él ha madurado; así, la vida del amor que brota del genio artístico debe transmitirse a todos los demás, supliendo con la multiplicidad de los sujetos receptivos lo que pierde en intensidad con este tránsito ${ }^{78}$. El amor, tal como se manifiesta en el terreno artístico, constituye una analogía, en lo que se refiere a la generación de la forma, del amor natural y su fuerza reproductora, si bien el amor natural debe elevarse, desde la rudeza del mero impulso y la simple voluntad de existir, hasta el aprecio de la forma pura. El amor natural debe convertirse

\footnotetext{
${ }^{74}$ Ibidem, II 416, 430.

75 Ibidem, II 439.

76 Ibidem, II 36.

77 Ibidem, II 23.

78 Ibidem, II 429, 76-77.
} 
en amor libre, esto es, en un amor que, tras liberarse por completo de la existencia real, se pierde en la Idea del Universo. En esto consiste la esencia última y la tendencia final de todo arte auténtico, que cifra su importancia para la Humanidad sólo en el hecho de que en él se capta la Forma o Idea liberada de toda referencia a la existencia, con sus necesidades y su rudeza ${ }^{79}$. Sólo en el arte llega el amor a ser completamente impersonal, pues en la belleza no se concibe al yo, sino al amor que se capta a sí mismo, algo impersonal en el que Sujeto y Objeto quedan liberados de cualquier referencia a la existencia concreta, sumergiéndose en la pura apariencia de la Idea estética. Mediante el amor a lo bello, el yo desaparece momentáneamente en la pura contemplación de la apariencia bella, alcanzando la ilusión momentánea de penetrar en la grandiosidad del ideal, superando la realidad común. Tomado en sentido estricto, lo captado en este momento por el amor no es, evidentemente, el amor mismo, sino sólo aquello que constituye el fundamento y meta del amor: el Uno; por consiguiente, el amor no es sino un sentimiento reflejo, suscitado en el ánimo del individuo por la captación intuitiva, a través de la obra, de la unidad esencial inmanente en la pluralidad fenoménica.

A juicio de E. von Hartmann, la definición trahndorffiana de lo bello como amor que se concibe a sí mismo no anula la definición hegeliana de lo bello como "apariencia sensible de la Idea" 80 , sino que la complementa, explicando lo que Hegel deja sin aclarar: "la razón de la felicidad infinita que se alcanza a través de lo bello, la profunda conmoción del sentimiento que produce, y la elevación de éste último a la impasible beatitud de los dioses"81. Según Hartmann, la definición hegeliana de la belleza es excesivamente fría, por lo que la definición trahndorffiana le añade una dimensión sentimental de la que antes carecía: en la captación de la Idea en la apariencia estética, el amor se concibe o concuerda consigo mismo, encontrando una autosatisfacción estética que, a pesar de su carácter pasajero e ilusorio, abre al sujeto la verdadera perspectiva de la eternidad 82 .

79 Ibidem, II 52, 430, 174; II 51; II 3-4.

80 Hegel, G. W. F., Lecciones sobre la estética (Traducción de A. Brotóns Muñoz), Akal, Madrid, 1989, pág. 85.

81 HARTMANN, E. von., Op. cit., pág. 148.

82 Ibidem. Todo ello prueba, a juicio de E. von Hartmann, que la estética de Trahndorff no puede ser definida ni como un idealismo abstracto, ni como un simple formalismo, sino como un idealismo concreto, parecido al de Hegel, si bien Trahndorff, a juicio de Hartmann, no llega a desarrollar la verdad positiva de este tipo de idealismo (algo que él sí creyó llevar a cabo en la segunda parte de su estética, titulada Philosophie des Schönen, y publicada en 1887 [2 ${ }^{a}$ ed. Wegweiser-Verlag, Berlín, 1924]). 


\section{7.- La belleza del arte}

A continuación, Trahndorff pasa a analizar las condiciones de posibilidad de lo bello. Estas son: la simetría [Ebenmass], la armonía [Harmonie] y la expresión [Ausdruck]. Trahndorff previene contra una posible confusión de lo agradable [das Angenehme] con lo bello; lo agradable consiste en una adecuada constitución de la forma sensible que facilita la concepción de un tema determinado, mientras que lo bello no tiene nada que ver, en principio, con la existencia, sino que se basa en la forma, en tanto que en ella (como algo sensible) aparece la Forma (entendida como lo suprasensible o Idea) ${ }^{83}$; también está muy lejos de constituir una determinación aceptable de la esencia de lo Bello la simple unificación de las tres condiciones mencionadas (simetría, armonía y expresión), pues, según Trahndorff, lo bello permanece siempre como algo en última instancia inexpresable, que no posee su fundamento de determinación en ningún concepto sino en algo que se encuentra más allá de toda actividad conceptual ${ }^{84}$. El concepto habitual de lo bello como "unidad en la multiplicidad" tampoco nos ofrece una definición válida de la belleza, ya que no sólo se aplica a lo bello, sino a todo pensar y actuar, a la ciencia y al ámbito de la ética, e incluso al mundo entero con sus series de desarrollo y sus distintas clases de fenómenos, ya que la dualidad unidadmultiplicidad condiciona la existencia misma ${ }^{85}$. Todo lo dicho contribuye a asentar la firme convicción de que resulta imposible construir obras artísticas siguiendo reglas: la verdadera obra de arte sólo puede surgir de la vida del amor que se concibe a sí mismo en la inspiración del genio ${ }^{86}$.

Para Trahndorff, como hemos indicado, lo bello consiste en una intuición fantástica de una forma cerrada, en la que el sujeto parece desaparecer momentáneamente, y de la que se ha eliminado toda referencia a la existencia como tal, quedando sólo la pura Forma, esto es, la relación ideal del principio vital productor con la multiplicidad del fenómeno. Cuando la imagen artística interna del artista llega a constituirse en obra de arte externa, queda ligada nuevamente a la existencia, a través del material (mármol, lienzo, etc.) al que se adhiere para llegar a ser accesible a todos. Sin embargo, esta existencia es sólo un medio para la aparición de la Forma ideal, mientras que en la realidad natural la forma es el medio que hace posible la existencia

\footnotetext{
83 TRAHNDORFF, K. F. E., Op. cit., I 92-93.

84 Ibidem, I 96.

85 Ibidem, II 41.

86 Ibidem, II 428.
} 
misma ${ }^{87}$. Todo lo bello consiste únicamente en imágenes, pues sólo en el aparecer puede ser concebida con cierta plenitud la Forma del Universo. Por eso, las bellas artes exponen la Forma del Universo únicamente bajo la forma de la apariencia, o dicho de otro modo, la esencia del arte es la apariencia. La apariencia estética es, pues, el aparecer de la Forma del Universo (es decir, de la Idea) en una imagen artística, y se contrapone a la realidad es decir, a la aparición de la Forma del Universo como devenir 88.

El Ser, o la Esencia-en-sí, no es ni algo múltiple, cuyas características pudieran ser percibidas y contrapuestas al fenómeno, ni algo concreto, que estuviese enfrentado como miembro de una multiplicidad a otros seres concretos, de manera que pudiese ser determinado a través de ellos; por eso no puede nunca librarse de la manifestación, ya que sólo a través de ella puede aparecer y ser concebido ${ }^{89}$. Es su inmanencia y su secreta vida interna lo único que hace bello al fenómeno; pero en-y para-sí mismo no es aún lo bello, sino la Idea que reposa en las profundidades de la Divinidad, o, dicho de otra manera, lo sublime de la Idea, que constituye la Santidad de lo Divino, oculta y simplemente vislumbrada ${ }^{90}$.

En la obra artística todo apunta a subordinar las manifestaciones de la existencia y del devenir al ideal que, no obstante, nunca puede aparecer sin el devenir fenoménico. Si se logra elevar la apariencia estética de la obra artística al ideal, es decir, si el artista logra ofrecer a la concepción la verdadera Forma del Universo de manera mediata e inmanente, la obra de arte triunfa por completo, y el signo de su triunfo es su capacidad para suscitar ilusión. La ilusión no es otra cosa que la victoria del amor, que se concibe y se contiene sentimentalmente a sí mismo en lo Bello, al reconocer en él la verdad de la Idea ${ }^{91}$.

La ilusión provocada por el arte no es un engaño vulgar. Los engaños suscitados por imágenes vivaces de la realidad natural no son arte; tampoco lo es aquella especie de autoengaño [Selbsttäuschung] que finge el ser humano para olvidarse de la realidad por un momento, y entregarse a fantasías o ensoñaciones que dulcifiquen su existencia. En este sentido Trahndorff señala que:

87 Ibidem, II 53.

88 Ibidem, I 214, I 97, 39, I 90, I 217, II 381-382.

89 Ibidem, I 189, II 383.

90 Ibidem, I 96-97, 173. Con la expresión "sublime" no debe entenderse en este contexto aún lo "sublime" estético, ya que éste requiere, además de la Idea, un fenómeno que sea superado por ella.

91 Ibidem, II 381, 43, 83, 23. 
"iAy del arte si éste fuese su único fin, y ay de la realidad si nos viésemos obligados a olvidarla hasta ese extremo! ;Ay si tuviésemos que olvidar lo que es su verdad misma! No debemos olvidar lo que en la realidad haya de verdadero, sino aquello a través de lo cual nos engaña; y es ella la que nos suele engañar, no el arte. Muy a menudo nos engaña con lo artificioso que surge de la lucha de la fuerza aislada con la debilidad, y es esta lucha lo que tenemos que olvidar, rechazando lo antinatural, para vivir en contacto inmediato con el Ser y la Verdad más íntima del Universo; y esto se consigue a través de la ilusión. Es la ilusión la que nos ofrece inmediatamente la Verdad de la vida, y es precisamente ella la que nos permite olvidar la falsedad; es también la ilusión el medio de vivificar y reafirmar cada vez más la Verdad y el Ser en su manifestación, asumiendo una naturaleza cada vez más pura y libre de la lucha con lo débil que hay en nosotros" $" 92$.

El concepto de "ilusión" nos permite profundizar en los diversos grados de perfección que pueden darse en la experiencia estética. Como hemos visto, la obra artística es una apariencia estética que permite evocar en la conciencia de cada individuo que la contempla, como fenómeno subjetivo, la correspondiente imagen artística plenamente determinada y concreta, tal como el artista la ha proyectado en ella; pero no todo el mundo está preparado para que la obra provoque en él la ilusión de poder obtener, mediante la pura apariencia estética, un contacto inmediato con la verdadera Forma del Universo, ni con el amor que se concibe y se satisface a sí mismo. Y, sin embargo, sólo a través de esta ilusión nos es posible penetrar en la más íntima sacralidad de la Belleza misma, siendo todos los posibles grados inferiores del goce de lo bello meros pasos en el vestíbulo de su templo. En cambio, la ilusión más fuerte se produce cuando alguien, que posee una naturaleza receptiva para lo bello y un sentido estético educado, entra en contacto por

92 Ibidem, II 49-50. "Wehe der Kunst, wenn sie keinen andern Zweck hätte, und wehe der Wirklichkeit, wenn wir sie so vergessen müssten, wenn wir selbst vergessen müssten, was an derselben Wahrheit ist! Nicht die Wahrheit in derselben sollen wir vergessen, sondern das, wodurch sie uns täuscht, und sie täuscht uns am meisten, nicht die Kunst. Sie täuscht uns nur $z u$ oft durch Unnatur, entstanden durch den Kampf isolierter Kraft mit der Schwäche, und diesen Kampf sollen wir vergessen, dieser Unnatur entsagen, um in unmittelbarer Berührung zu leben mit dem Sein und der innersten Wahrheit des Universums, und diess geschieht durch die Illusion. Sie giebt uns grade die Wahrheit als unmittelbares Leben, und was wir darüber in der Wirklichkeit vergessen, ist eben die Unwahrheit, so wie jene Illusion das Mittel, die Wahrheit und das Sein immer mehr in der Erscheinung zu beleben und zu befestigen, indem wir die Natur immer reiner und freier vom Kampfe mit der Schwäche in uns aufnehmen” 
vez primera con la obra maestra de un genio que hasta ese momento le resultaba desconocida ${ }^{93}$.

Trahndorff señala que la ilusión y la felicidad del amor que se concibe a sí mismo serán tanto más elevadas cuanto más clara y perfecta sea la relación representativa de la "idea microcósmica" contenida en la obra artística con la "Idea macrocósmica", y cuanto más fuertemente aquélla impela a concebir o presentir ésta última, ya que sólo en la "Idea macrocósmica" se da la Unidad plena y total, mientras que la "idea microcósmica" constituye únicamente un ejemplo especial de la misma. Ahora bien, la "idea microcósmica" resultará tanto más adecuada para apuntar a la "Idea macrocósmica" y despertar el presentimiento de su Unidad Absoluta, cuanto mejor y más inmediatamente se encuentre representada como apariencia estética -a modo de encarnación de lo Divino- la individualidad expuesta en la obra de arte. Según Trahndorff, tal objetivo sólo se consigue en dos casos: en la representación plástica de los dioses de la naturaleza, y en la representación ético-teleológica de la encarnación humana de lo Divino. Lo primero se da en el arte clásico; lo segundo en el arte romántico.

Para la intuición y la religión de la Naturaleza del griego, el objeto amado era aún algo extrínseco, fugaz y cambiante (tal como se da p. ej. en el amor sexual estéticamente ennoblecido), al que únicamente podía otorgar eternidad a través de una figura artística semejante a él mismo; por eso veneraba la estatua del dios, en la que veía representada la única encarnación de lo Divino que conocía; para él lo bello debía ser algo estático, inmutable y existente por sí mismo ${ }^{94}$. El objeto del amor de los germanos, era, por el contrario, algo interno; no se trataba de la mera plenitud vital extrínseca, sino del principio ético, que determina y embellece la vida en su totalidad; por eso, lo predominante en ellos era el amor a la libertad, esto es, un amor que no se dirige sólo a la forma en sí misma, sino que se centra, sobre todo, en la expresión, y que exige al ser humano una fidelidad total en la unión de la propia vida con la del otro ${ }^{95}$. Lo que amaban los germanos era la encarnación de lo Divino en el prójimo; y es esta idea de la encarnación humana de lo Divino, como objeto de amor y respeto, el elemento más importante del Romanticismo, tal como se pone de manifiesto en el culto a Cristo y la Virgen María, o en el amor cortés medieval (por muchos elementos impuros que pudieran añadirse a este último). Aquí ya no son las imágenes lo venerado, sino que tales imágenes son sólo símbolos que expresan sensiblemente la

\footnotetext{
93 Ibidem, II 416.

94 Ibidem, II 352-354.

95 Ibidem, II 351-352
} 
interioridad espiritual, el amor, que "en cada momento se encuentra en camino hacia su propia purificación y la liberación de la individualidad"96. A juicio de Trahndorff, fue el Cristianismo el que introdujo en los bárbaros del norte la semilla para que este tipo de amor superior pudiese desarrollarse, recibiendo él, a su vez, la impronta romántica a través del espíritu germánico ${ }^{97}$. Con todo, el desarrollo del arte cristiano se vio obstaculizado desde el principio por una tendencia equivocada, que llevó a prescindir casi por completo de la representación de los individuos comunes y centrarse en la representantes de la humanidad "divinizada" (Cristo, María, etc.), cuando en el espíritu del Cristianismo puro se encontraba la propuesta de extender la encarnación humana de lo Divino a todos los individuos, a fin de reconducirlos a la Unidad Suprema a través de dicha divinización. Esta carencia sólo podrá superarse en una nueva época futura del arte, en la que la forma dogmática del Cristianismo histórico (la encarnación humana de Dios en uno, o en unos pocos individuos simbólicos) dé paso a lo que Trahndorff denomina "el espíritu del Cristianismo puro" [den Geist des reinen Christentums], en el que la encarnación de Dios en todos los individuos llega a ser el contenido universal de la conciencia ${ }^{98}$.

\footnotetext{
96 Ibidem, II 355. "... und steht also auch in jedem Moment auf dem Wege zu ihrer eignen Reinigung und Befreiung von der Individualität”

97 Ibidem, II 356-357.

98 Sobre este punto cf. HARTMANN, E. von. Op. cit., pág. 152. A nuestro juicio, parece evidente que existe un paralelismo entre las propuestas estéticas y artísticas de Trahndorff y la actividad llevada a cabo por la escuela contemporánea de los pintores Nazarenos en Roma. Esta escuela tenía como programa llevar a cabo un renacimiento del arte cristiano, partiendo de la pintura religiosa de la Edad Media tardía en Alemania y del Quattrocento italiano. Sus fundadores fueron los alemanes Johann Friedrich Overbeck (1789-1869), Franz Pforr (1788-1812), Joseph Wintergerst (1783-1867), Joseph Sutter de Linz (1781-1866) y los suizos Georg Ludwig Vogel (1788-1879) y Johann Konrad Hottinger (1788-1828), quienes crearon en 1809 en Viena la "Lucas-Bund" o Hermandad de San Lucas. Ese mismo año viajaron a Roma, instalándose en el monasterio de San Isidoro; allí se les unieron otros pintores centroeuropeos, como Peter Cornelius (1783-1867), Friedrich Olivier (1785-1841), Wilhelm Schadow (1788-1862), Julius Schnorr von Carolsfeld (1794-1853) y C. Ph. Fohr (1795-1818). Influidos por las Efusiones del corazón de un monje amante del arte [Herzenergiessungen eines kunstliebenden Klosterbruders], obra publicada por W. H. Wackenroder en 1797, y por la serie de artículos publicados por Friedrich Schlegel en la revista Europa entre 1803 y 1805 , en los que se valoraba el arte de los maestros primitivos, se convirtieron en una especie de "monjes artistas", miembros de una comunidad artística espiritual, cuyo signo distintivo era llevar el pelo largo con la raya en medio, peinado alla nazarena, que recordaba a Cristo. Su arte, francamente confesional -muchos miembros de la comunidad se convirtieron al catolicismo, y todos ellos aspiraban a alcanzar la inspiración artística en el momento de recibir la Comunión-, seguía los modelos ofrecidos por el "antiguo arte alemán" (Durero y su círculo), Fra Angelico, B. Gozzoli, e incluso el propio Rafael (quien, paradójicamente, constituía el gran modelo de los pintores clasicistas). En todo caso, el elemento religioso forma el tema
} 


\section{8.- La evolución de los ideales artísticos}

En la estética de Trahndorff, los ideales artísticos están sometidos a un desarrollo evolutivo que atraviesa diferentes grados. En general, nuestro autor utiliza para interpretar dicha evolución dos categorías contrapuestas: "lo plástico" y "lo ético-teleológico". La primera designa aquella dimensión del arte consagrada a la captación de un momento fijo en la fugacidad del devenir, en función de un interés concreto; la segunda apunta a la aprehensión estética del devenir para-sí, esto es, en relación con el ser interno; en cualquier caso, aquí no se enfoca el devenir en relación con lo que deviene, sino en relación con la interioridad de su realización, esto es, en relación con el querer y su determinación motivadora ${ }^{99}$.

Las distintas artes, por su naturaleza específica, se aproximan más a una u otra de las categorías mencionadas; todo depende de si se trata de captar el ideal bajo la forma de un momento concreto, extrayéndolo del fluir real y fijándolo eternamente, como sucede en el arte que llamamos clásico, o se trata de captar el ideal bajo la forma de la interioridad que domina el devenir, como sucede en el arte que denominamos romántico ${ }^{100}$. Si, en cambio, se intenta captar en el ideal el Ser mismo, suprimiendo completamente su conexión con el devenir, se suprime toda significación estética; entonces el Ser es concebido únicamente bajo la forma de un vago presentimiento, y el intento de representarlo sensiblemente nos da el arte oriental $^{101}$, al que Trahndorff, apartándose de Hegel y coincidiendo con Weisse ${ }^{102}$, adjudica una posición extraestética, al margen del arte clásico y romántico; de ahí que en la Aesthetik apenas le preste atención.

En la Antigüedad clásica, las artes dominantes eran la arquitectura, la escultura, la danza y lo que Trahndorff llama "poesía plástica" (expresión que no aclara, pero que parece apuntar al carácter "euclidiano" -por emplear un término tomado de Spengler- de la poesía greco-latina); la pintura

principal de este arte, marcadamente romántico, caracterizado por el elemento irracional, el torrente de anhelo y una plena exuberancia de sentimientos. Sobre los Nazarenos, cf. Novotny, F., Pintura y escultura en Europa 1780/1880, Cátedra, Madrid, 1994 (5ªd.), pp. 108 y ss., y ARNALDO, J. El movimiento romántico, Historia del Arte 16, n²39, Madrid, 1989, pp. 109 y ss.

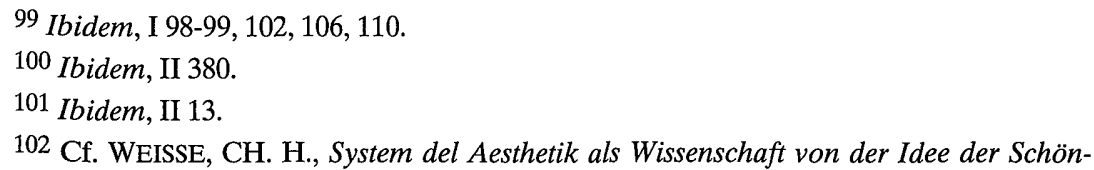
heit, I 303. También para Weisse el arte oriental es un mero paso previo al arte bello propiamente dicho. 
estaba, a su entender, excesivamente ligada a la plástica, y el mimo no pudo desarrollarse plenamente, por el impedimento que suponían las máscaras trágica y cómica; por último, la música jugaba en este período un papel secundario, al utilizarse por lo general como mero acompañamiento de la poesía. En la Edad Media y Moderna, la arquitectura, la escultura, la danza y la "poesía plástica" pasaron a un segundo plano, ocupando su lugar la "poesía ético-teleológica" (es decir, una poesía guiada por motivos líricos y dramáticos), la música, el mimo y la pintura ${ }^{103}$. La escultura, que ya no contaba con la posibilidad de representar dioses antropomórficos, y que aún no se atrevía a imitar simples hombres vivos, se limitó a representar como si fuesen figuras ideales (a la manera de nuevos mitos) a aquellos sujetos que quedaron inmortalizados en la conciencia popular por sus obras y hechos milagrosos ${ }^{104}$.

Por lo que respecta al futuro del arte, Trahndorff coincide con Hegel en que existe un proceso de decadencia, aunque la atribuye a motivos diferentes. La pérdida de vigor de la fe cristiana hace que también el arte entre en un proceso de declive. En vez del amor a lo más elevado y al ideal, una frívola sentimentalidad y una indiferencia carente de bríos han pasado a dominar el panorama artístico ${ }^{105}$; se ha producido una confusa mezcla de estilos artísticos, y una torpe labor crítica termina por completar un panorama desolador, en el que resulta casi imposible recuperar el sentido para al arte auténtico. Como sucedió entre los romanos, el arte queda rebajado a ser un lujo refinado, reservado a los "connaisseurs", y la opinión de la masa ahoga al verdadero genio, condenando su obra si ve que no se somete a los dictados del mal gusto dominante ${ }^{106}$.

103 TrAHNDORFF, K. F. E. Op. cit., II 333-340 y 341-343.

104 Ibidem, II 377-378. Esta idea también la recoge Weisse: cf. System..., II 178-181.

105 Ibidem, II 356, II 400.

106 Ibidem, II 440-447, II 425, 430. E. von Hartmann (cf. Op. cit., pp. 154-155) considera que, tras el período "romántico" medieval, la creencia cristiana ya había agotado los estímulos estéticos que en ella se encontraban, y entró en un proceso de disolución interna, de manera que, a su juicio, difícilmente podrá surgir aún un gran arte a partir de la fe cristiana. En todo caso, la esperanza de Trahndorff es que la mediocridad del arte de su época se vea superada mediante un arte renovado que suponga una síntesis de lo clásico y lo romántico, síntesis que debe significar, al mismo tiempo, el logro del nivel más elevado de pureza y universalidad del que es capaz el arte (cf. Aesthetik, II 405). 


\section{9.- El problema de la belleza natural}

La relación entre belleza natural y belleza artística queda poco clara en la Aesthetik de Trahndorff. Ciertamente, no rechaza de modo expreso lo bello natural, como hace Hegel, ni presenta un principio de belleza tan restringido que termine por excluir la belleza natural, como sucede, p. ej. en Schleiermacher; es cierto, asimismo, que, junto al principio de la producción artística de lo bello, Trahndorff habla de una posible percepción de la belleza en la "intuición del mundo" [Weltanschauung] o en el "concebir el mundo" [Erfassen der Welt]; pero su interés fundamental gira siempre, a la postre, en torno a lo bello artístico. Trahndorff, se plantea, no obstante, la cuestión de si es posible encontrar en las formaciones naturales lo bello ideal, o si sólo puede hallarse en las imágenes artísticas, y responde diciendo que en las formaciones naturales, el ideal, como algo contenido en la totalidad del Universo, se concibe mediata y conjuntamente a través de la relación de la formación aislada individual con dicho todo; en cambio, en la imagen artística, el ideal es concebido primeramente bajo la forma de un miembro del todo, y luego, a la vez, como expresión específica e inmediata del Ser; así ambas formas de referencia al Ser, la mediata y la inmediata, confluyen en una sola, haciendo que en su filosofía el ideal artístico cobre primacía frente al ideal natural ${ }^{107}$.

Esta observación de Trahndorff no debe entenderse como si se negase el carácter microcósmico de la formación natural; sólo significa que la concepción del ideal en las estructuras naturales microcósmicas está, en primera instancia, mediado por su relación con la "Idea macrocósmica", mientras que en las imágenes artísticas, a esta significación microcósmica se añade una segunda forma, inmediata, de sensibilización del Ser ideal. Ya hemos visto cómo para Trahndorff el mejor ejemplo de esto lo ofrece la encarnación humana de lo Divino. Trahndorff, pues, al igual que Hegel, traza el límite de lo bello natural por debajo del hombre, lo que resulta incorrecto; asimismo, tampoco parece percatarse de que sólo una pequeña porción de lo bello artístico superaría el nivel de lo bello natural. No se da cuenta, en definitiva, de que la verdadera razón de la superioridad de lo bello artístico sobre lo bello natural se encuentra en la relación que media entre la apariencia estética y la realidad ${ }^{108}$.

107 Ibidem, II 35.

108 E. von Hartmann señala que, afortunadamente, Trahndorff no ha cometido el error de invertir el orden de los términos, situando lo bello natural por encima de lo bello artístico. Cf. $O p$. cit., pág. 156. 
10.- Lo bello y sus modificaciones particulares: lo sublime, lo trágico, lo cómico, lo humorístico

\section{a) El sentimiento de lo bello}

Cuando la Idea o "Forma del Universo" se hace patente en las formas intuitivas espacio-temporales por medio de una imagen adecuada, la concepción de dicha imagen suscita en nosotros el sentimiento de lo bello:

"Si encontramos una imagen que constituye un todo completo, bien sea por la relación del Ser con la existencia, bien sea por la relación de la unidad con la pluralidad, de manera que en ella se concibe por completo en forma intuitiva la Forma del Universo -pudiendo ser comprendido lo múltiple con sus contradicciones, a partir de la unidad y dentro de dicha forma-, entonces podemos decir que lo bello se encuentra en tal imagen, que hemos concebido bajo la forma de lo bello la Forma del Universo (siempre que se trate de un concebir por concebir, es decir, un concebir de la forma pura en sí misma), y, por tanto, que lo bello no es otra cosa que la Forma del Universo, en la medida en que, en el concebir por concebir mismo, dicha Forma se nos abre por completo bajo las formas de la intuición (espacio y tiempo)"109.

\section{b) El sentimiento de lo sublime}

Siguiendo la línea marcada por Schelling, Ast y Hegel, Trahndorff trata de explicar lo sublime como trascendencia de la Idea respecto del fenómeno. Cuando la Idea o "Forma del Universo" se eleva por encima de las formas intuitivas espacio-temporales, yendo más allá de ellas, la concepción de esta relación de superioridad produce los sentimientos de lo grandioso y lo subli$m e$. La diferencia entre ambas categorías no queda suficientemente clara en Trahndorff. Sobre la primera nos dice que:

109 Cf. TRAHNDORFF, K. F. E. Op. cit., I 80-81. "Liegt nun ein Bild, welches dem Verhältnis des Seins zum Dasein oder der Einheit zur Vielheit nach, und in so fern es dadurch ein geschlossenes Ganzes bildet, also in so fern darin die Form des Universums erfasst wird ganz in diesen Umfange der Anschauungsform, so dass alles Manningfaltige in seinen Gegensätzen noch innerhalb dieses Umfanges aus der Einheit verstanden werden kann (insofern es nämlich erfasst wird für das Erfassen, also die Form rein für sich): so ist in dem Bilde das Schöne, und wir haben die Form des Universums erfasst, als das Schöne, und können also sagen: Das Schöne sei nichts andres als eben die Form des Universums, in so fern sie bei dem Erfassen für das Erfassen völlig aufgeht in der Form der Anschauung (Raum und Zeit)." 
“Cualquiera que queda fuera de la forma de la intuición, y en relación con una unidad superior, se convierte en algo grandioso, y su relación con el Todo se denomina relación de grandiosidad"110.

Por lo que se refiere a lo sublime, afirma que, si la Forma o Idea supera tanto a la imagen que no puede ser abarcada intuitivamente a través de la relación que guarda dicha imagen como parte de un Todo superior, sino que sólo puede ser presentida -con la ayuda de una serie de indicaciones sensibles- como algo situado más allá de toda intuición, obtenemos entonces la concepción de lo sublime:

“... lo Sublime no es... otra cosa, que la Forma del Universo, no intuida inmediatamente en la imagen por medio del "concebir por concebir", sino sólo presentida a través de una serie de indicaciones"111.

Concluye esta reflexión indicando que, si lo contrario de lo bello es lo feo, los contrarios de lo grandioso y lo sublime serían lo horroroso y lo temible, respectivamente.

\section{c) Lo trágico y lo cómico}

Según Trahndorff, la Idea, o "Forma del Universo", es el fundamento de toda verdad, por cuanto es lo que determina la relación de la existencia con el Ser (o, lo que es lo mismo, del fenómeno con la esencia). En tanto se la piensa como lo inmanente al fenómeno, la Idea es concebida en su verdad; pero la Idea como fundamento de determinación inmanente puede, a su vez, no ser vista como parte del fenómeno, como contenido ideal del mismo, sino que puede también ser ignorada, o concebida falsamente, como algo que ella no es. Cuando la Idea falsamente concebida es puesta como verdad del fenómeno, nos hallamos ante el fatal error que da origen a lo trágico.

La única concepción seria consiste en concebir la verdad como verdad y la falsedad como falsedad; pero si la falsedad de la concepción no es conocida como tal, ni se plantea firmemente como algo contrario a lo verdadero - de manera que conduzca a la aniquilación trágica, mediante el desafío a las fuerzas del Universo-, sino que la falsedad se refiere, a su vez, a fenómenos falsos, se aniquila a sí misma, puesto que sólo puede existir en la medida en

110 Ibidem, I 81-82. "Jedes einzelne Bild, welches nur als Glied eines ausser der Anschauungsform liegenden Ganzen und in Beziehung auf eine höhere Einheit erfasst werden kann, wird dadurch ein grossartig Glied, und das Verhältniss derselben im Ganzen wird ein grossartiges Verhältiniss genannt."

111 Ibidem I 82. "So ergiebt sich das Erhabene, und dies ist wieder nichts anders, als die Form des Universums in so fern sie beim Erfassen für das Erfassen nicht mehr in dem Bilde unmittelbar angeschaut, sondern nur vermöge der Andeutungen geahnet wird." 
que se pone como verdad. En este caso, las fuerzas del Universo se ven liberadas de la necesidad de aniquilar al que se les opone, puesto que es él quien se aniquila a sí mismo. Esta falsedad, basada en la falsedad de la concepción, no es ni seria, ni trágica; no puede denominársela siquiera error, sino que es una simple tontería, y la alegría que invade el ánimo porque la Némesis se ha librado de su tarea, o por la autoaniquilación, tanto de la tontería, como del tonto, cuando éste recibe su merecido, es lo cómico o ridículo112. Lo cómico siempre debe tener como trasfondo, inexpresado pero evidente, la seriedad de la Idea, la cual es concebida con él, si bien no de manera inmediata, sino mediatamente, como elemento contrario de la tontería que se aniquila a sí misma; allí donde falta dicha relación con la verdad de la Idea, lo cómico se transforma en mera frivolidad, y es estéticamente rechazable ${ }^{113}$.

\section{d) Lo humorístico}

En su explicación del humor, al igual que sucedía con lo cómico, Trahndorff acude a la relación del sujeto con la verdad y la falsedad. Al concebir los tontos habitualmente la vida en el marco de una continua aniquilación de la verdad a través de la falsedad, fomentan a su vez ellos mismos esa falsedad, haciéndose ridículos (puesto que, no sólo son incapaces de captar sensatamente la verdad y promoverla, sino que además son tan estúpidos como para asumir tareas que sólo podrían ser resueltas con seriedad). Cuando la conciencia reflexiona sobre esta situación, no puede por menos que sentir una profunda lástima por la miseria de la Humanidad y por los inútiles esfuerzos que malgastan los seres humanos en tareas que consideran serias, mientras que, paralelamente, ve la profunda seriedad que subyace a lo que habitualmente se considera ridículo. Esta concepción del mundo es el humor, que, desde un punto de vista objetivo, es alegre y risueño, pero desde un punto de vista subjetivo es algo doloroso y desgarrador; con todo, ambas perspectivas son aspectos que el humor incluye necesariamente en sí, y que no pueden darse por separado ${ }^{114}$.

112 Ibidem, II 33-34. E. von Hartmann considera que la definición trahndorffiana de lo cómico como autoaniquilación de la estupidez es de las mejores que se han formulado para tratar de explicar este efecto estético: Cf. $O p$. cit., pág. 420.

113 Ibidem, § 22.

114 Ibidem, II 34. 


\section{1.- La division de las artes}

La división de las artes propuesta por Trahndorff se caracteriza por tres peculiaridades. En primer lugar reconoce al mimo y a la danza un papel de gran importancia en el sistema de las artes, hasta el punto de que considera que sin ellas las restantes artes pierden su significación relacional y, por tanto, su vida verdadera ${ }^{115}$; en segundo lugar, Trahndorff establece una clara diferencia entre la arquitectura y la jardinería -como artes no libres, relacionadas con las necesidades de la existencia-, y las artes libres -que dependen, todo lo más, de la simple participación social-; por ello les asigna a ambas un lugar especial en el sistema de las artes, no incluyéndolas en el grupo del arte bello en sentido estricto, es decir, del arte bello libre ${ }^{116}$. En tercer lugar, divide las bellas artes libres en artes del oído y artes de la vista ${ }^{117}$, o artes del tiempo y artes del espacio118 -según que la Forma o Idea se proyecte en el ámbito de los fenómenos bajo la forma de intución temporal o espacial.

Sin embargo, en otro pasaje de su obra abre una nueva línea divisoria (sin explicar los motivos de su cambio de perspectiva) estableciendo una clasificación tripartita en artes del tiempo, del espacio y del movimiento ${ }^{119}$. Introduce las artes no libres, o artes sometidas a los imperativos de la necesidad, que habían sido excluidas en la primera división, añadiéndoles el arte de la elocuencia120; asimismo, asigna a la jardinería y a la arquitectura una relación mutua análoga a la que tienen en las artes plásticas libres la pintura y la escultura. En esta división, incluye la música en el grupo de las artes del movimiento, junto con el mimo y la danza, de manera que en el grupo de las artes temporales sólo pone la poesía ${ }^{121}$, añadiendo que la poesía en las artes libres guarda la misma relación con la pintura y la escultura que la elocuencia con la jardinería y la arquitectura ${ }^{122}$. Cabría esperar que Trahndorff hubiese plasmado estos paralelismos en las tablas divisorias que presenta en

\footnotetext{
115 Ibidem, I 220.

116 Ibidem, I 183-184.

117 Ibidem, I 221.

118 Ibidem, II 8, 11.

119 Ibidem, II 13, 14.

120 Ibidem, II 11.

121 Ibidem, II 13, 14.

122 Ibidem, II 9.
} 
su libro; pero ni en la primera ${ }^{123}$ ni en la segunda tabla ${ }^{124}$ es posible seguir claramente esta correlación.

La división de la poesía que lleva a cabo Trahndorff es realmente extraña. Distingue en ella cuatro partes: 1. La ética (?) [Ethik] o poesía del devenir [Poesie des Werdens], subdividida en épica y dramática [Epik, Dramatik]; 2. Lírica o poesía del ser [Lyrik oder Poesie des Seins]; 3. Plástica o poesía idílica [Plastik oder idyllische Poesie]; y 4. Didáctica [Didaktik]. Como vemos, Trahndorff incluye la didáctica en la poesía, cuando en realidad es un arte no libre, ligado a la necesidad; también resulta extraño que considere la poesía como arte del oído cuando sería más adecuado considerarla, a la manera de Schelling y Hegel, como un arte de la fantasía. Sólo podría incluirse dentro de las artes del oído la forma de disponer las palabras de manera que suenen bellamente, factor que ciertamente hay que incluir en el arte poético, pero como un momento superado en el mismo y que no constituye su esencia específica. Trahndorff, sin embargo, pone todo el énfasis en la actividad intelectual del entendimiento; es verdad que en una ocasión afirma que la poesía sólo puede captar la Idea en imágenes intuitivas, y, por consiguiente, piensa en imágenes ${ }^{125}$; pero no extrae de esta afirmación

123 Ibidem, I 221: "Cuando revisamos la totalidad de las bellas artes, y la ordenamos en función de si se hallan libres de las necesidades de la existencia, obtenemos la siguiente tabla: I. En el grado de la necesidades de la existencia: 1) La jardinería [die schöne Gartenkunst]; 2) La Arquitectura [die Baukunst].

II. En el grado de la participación social:

A) Por el oído: 1) Libre configuración del sonido, sin relación con necesidad alguna: Música [Musik]; 2) Libre configuración del sonido como medio de designación en el lenguaje: Poesía y Elocuencia [Poesie und Beredsamkeit].

B) Por la vista:

a) Artes de lo fijo y carente de movimiento: 1) Dibujo [die Zeichnungskunst]; 2) La configuración de imágenes [Bildnerei] con todas sus ramas, 3) El arte del grabado [die Kupferstichkunst] en toda su extensión; 4) La pintura [die Malerei].

b) Artes de lo viviente y móvil: 1) El Mimo y arte escénico [die Mimik und Schauspielkunst]; 2) La Danza [die Tanzkunst]."

124 En II 11, encontramos una tabla diferente, que corresponde a lo que Trahndorff denomina "el organismo del arte"; en esta tabla encontramos la siguiente división: klang]

Artes de lo TEMPORAL: Elocuencia [Beredsamkeit], Expresión armoniosa [Wort-

Poesía [Poesie], Música [Musik]

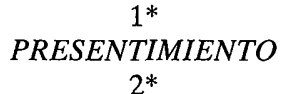

$2^{*}$

Artes de lo ESPACIAL: Danza [Tanzkunst], Arquitectura [Baukunst]

Mimo [Mimik], Dibujo [Zeichnendekunst]

125 Ibidem, II 86. 
conclusión alguna, limitándose a afirmar que "sólo el entendimiento habla $y$ comprende; en cambio la fantasía es muda y se limita a ver" ${ }^{126}$; con ello restringe la actividad de la fantasía a la visión, suprimiendo cualquier posibilidad de existencia de una fantasía sonora, y con ello la posibilidad misma de una fantasía poética; sólo le queda, por consiguiente, la posibilidad de plantear la actividad poética como una traducción de las imágenes contempladas en el interior de la fantasía en palabras, y viceversa, lo cual es manifiestamente erróneo.

La división en artes espaciales y temporales la deduce Trahndorff de manera un tanto artificiosa a partir de la tríada del "entender", "presentir" y "querer" como funciones principales del individuo libre127. En el ámbito del presentir no es posible ideal artístico alguno, porque aquí el ánimo sucumbe por completo ante lo ideal; los espíritus con esta disposición fundamental son visionarios de lo eterno, individuos que han logrado alcanzar la dignidad suficiente para entrar en comunicación inmediata con el Principio Supremo del Mundo. Se trata de una dirección espiritual que atañe a la religión, más que al arte128; por tanto, para el arte sólo quedan el entender y el querer. Para el entender, la Forma del Universo es algo pensado, interior al espíritu, mientras que para el querer constituye una realización, algo interiormente pensado que llega a exteriorizarse. La relación del entender da como resultado para la fantasía las artes temporales, mientras que la relación del querer da como resultado las obras del arte plástico, puestas exteriormente en el espacio129. Según Trahndorff, cuanto más se aproximan las artes de lo temporal (del entender) y de lo espacial (del querer) al término medio del presentimiento, parecen aproximarse también en mayor grado a lo Eterno, al Ser, como objeto de dicho presentimiento; por eso la música (a causa de su carácter evocador), el mimo y la danza, se encuentran más capacitadas para "presentir" el Ser Eterno que, por ejemplo, el arte plástico ${ }^{130}$

126 Ibidem II 13-14. “...denn nur der Vestand spricht, so wie er auch nur versteht. Die Phantasie ist stumm, sie sieht nur."127 Ibidem, II 6.

128 Ibidem, II 6-7, I 59.

129 Ibidem, II 7; E. von Hartmann no ve motivo alguno para establecer la relación apriórica que postula Trahndorff entre el entender y el tiempo, por un lado, y el querer y el espacio, por otro: Cf. $O p$. cit., pág. 538.

130 Ibidem, II 10-11. Trahndorff considera que la música se encuentra también más cerca de lo Eterno que la poesía por cuanto "lo visible concierne inmediatamente a la forma (es decir, la Idea), mientras que lo audible de la música asume una posición intermedia entre la forma y la existencia" ["das Sichtbare unmittelbar gleich auf die Form (d. h. die Idee) geht, das Hörbare der Musik aber seinen Standpunkt zwischen der Form und dem Dasein nimmt"]; este es el motivo de su enorme capacidad para penetrar con fuerza en nuestro interior. (Cf. Ibi- 
Trahndorff define la música como la configuración del movimiento sonoro en forma de notas, a fin de concebir la Forma del Universo, por el mero hecho de concebirla; esa estructura sonora, plenamente liberada de cualquier tipo de necesidad vital, debe servir como "expresión de la lucha de la Idea de la Forma con la materia"131, en la que se pone de manifiesto "la pugna entre la unidad y la multiplicidad de la Existencia" (o, dicho de otro modo, la "lucha entre la Forma y la Existencia"132). Precisamente la libertad que posee la música respecto de las necesidades de la vida determina su carácter fundamental [Grundcharakter der Musik]: ajustarse a las inflexiones de la vida inmediata: si en la vida existe una constante alternativa entre actuar y padecer, lo fuerte y lo débil, lo masculino y lo femenino, lo poderoso y lo dulce..., así como un progreso continuo de uno de estos extremos hacia el otro, la música debe recoger estas fluctuaciones de la existencia, depurarlas, y someterlas a una estructuración formal, valiéndose de la melodía y la armonía que, en su discurrir progresivo, adquieren diferentes configuraciones hasta llegar a la conclusión de la pieza. Así sucede en la música instrumental -en relación con la cual Trahndorff establece una curiosa comparación, al señalar que, si la epopeya es la expresión literaria de la lucha de la Forma con la Existencia, las sinfonías, conciertos, etc. pueden ser caracterizados como "puras epopeyas musicales" [reinmusikalische Epopöen]-; pero es en la música vocal donde la expresión de la Forma del Universo por el arte sonoro alcanza sus matices más delicados y su manifestación más adecuada, ya que la voz humana refleja en ella, de manera más inmediata, el estado normal de la vida, al que, como acabamos de decir, el arte musical debe procurar adecuarse ${ }^{133}$.

Hemos indicado al principio de este apartado que quizás el mayor mérito de la teoría trahndorffiana del arte es la atención que dedica al mimo y la danza, habitualmente postergados por la mayoría de los estetas ${ }^{134}$. Trahn-

dem, I 200). Frente a ello, E. von Hartmann considera que la música no precede en absoluto a la poesía; ciertamente sus medios de expresión sensible afectan más a la constitución del sistema nervioso del individuo, pero su esencia no queda afectada por ello, por lo que, al igual que las demás artes, mantiene su existencia en el ámbito separado de la apariencia estética; cf. $O p$. cit., pág. 539.

131 Ibidem, II 14. “... Ausdruck des Kampfes der Idee der Form mit dem Stoffe...”

132 Ibidem, I 200. “... die Musik, der Ausdruck jenes ausgleichendes Kampfes zwischen Form und Stoff, oder besser zwischen Einheit und Vielheit des Dasein..."

133 Ibidem, II 163-166, 208.

134 Georg Anton Friedrich Ast (1776-1841), discípulo de Schelling y de F. Schlegel, sí dedicó un pormenorizado estudio a la danza y al arte teatral en su System der Kunstlehre, oder Lehr- und Handbuch der Aesthetik, 1805, obra que E. von Hartmann supone debió 
dorff define el mimo como un arte de la expresión [Kunst des Ausdrucks] de la relación de la vida individual con el mundo ${ }^{135}$. El mero talento mímico copia la realidad dada a posteriori en la experiencia, igual que lo hace el pintor cuando dibuja; pero en ambos casos tal imitación no sirve en absoluto para caracterizar el auténtico arte ${ }^{136}$. El genio mímico alcanza su punto más alto y difícil cuando, por el contrario, llega a ser capaz de anular su personalidad empírica y asumir en sí el principio vital de una individualidad diferente, que determina a priori su expresión desde dentro, de forma adecuada a las exigencias que impone dicho principio vital ${ }^{137}$.

El mimo incluye en sí un triple movimiento: la mímica facial [Mienenspiel], la gesticulación [Gebärdenspiel], y el cambio de lugar [Ortsveränderung ${ }^{138}$. El hecho de que la obra de arte mímico consista únicamente en el devenir sucesivo de una serie determinada de manifestaciones vitales, es decir, el hecho de que no sea permanente, no da derecho alguno, según Trahndorff, a negarle la categoría de obra artística, puesto que se trata de una serie de momentos vitales claramente concebidos, que, gracias a este arte, se elevan idealmente a lo permanente, aunque dejando la posibilidad de su renovación continua:

"Al igual que la música es la voz supraterrenal que parece acompañar a la poesía, separándose de ella para alcanzar su independencia, el mimo y el arte teatral existen para representar de manera visible la lucha vital en aquellos estratos de la misma en los que domina el dolor y la necedad; en cambio, no deben exponer ni la victoria, ni la devoción, puesto que ambas

\footnotetext{
influir tanto en Trahndorff como en Schleiermacher. Ast incluye ambas artes bajo la que denomina "arte orquestal" [Orchestik], arte que, a su juicio, constituye la unidad del arte de la intuición (arte plástico) y del arte del sentimiento (arte musical) en el ámbito de la realidad (percepción sensible), porque a la vez construye formas con el cuerpo e indica afectos, con lo que está en condiciones de unir en sí el organismo y la vida anímica, que en la plástica se encuentran separados, restaurando la armonía natural del ser humano viviente, y con ella la libre vida armónica de lo bello. Según esto, el arte orquestal supone la unidad de lo Objetivo y lo Subjetivo en el grado de lo real, del mismo modo que la poesía alcanza dicha unidad en el grado de lo ideal (mediante la actividad fantástica del espíritu); más concretamente, de la manera en que la poesía dramática constituye la unidad de la poesía épica (objetiva) y lírica (subjetiva). Ast también señala que el mimo puede subdividirse en un subgénero objetivo y otro subjetivo, a saber, el arte de la danza mímica y el arte teatral vinculado al habla, división que corre paralela a la que en el arte plástico separa a la escultura de la pintura. Cf. AST, G. A. F. Op. cit., $\$ \S 100-106$.

135 Ibidem, II 278.

136 Ibidem II 283-284.

137 Ibidem, II 281, 284.

138 Ibidem II 287-288.
} 
son algo puramente interior, y no deben ser concebidas como algo externo o múltiple -lo que afectaría a su dignidad-, sino que deben concebirse como la unidad de lo interno, en la que parece abrirse la individualidad; por eso no pueden ser objeto de representación mímica." 139.

Frente al mimo como arte de los movimientos plenamente expresivos, Trahndorff define la danza como el arte del movimiento representado en el espacio, es decir, como el arte encargado de desarrollar y configurar las dimensiones del espacio, sus límites y relaciones mediante un movimiento temporal ${ }^{140}$. Según esta definición, parece como si Trahndorff entendiese la danza como un simple movimiento, formalmente bello, pero carente de expresión; sin embargo, no es así, ya que considera que esta representación espacio-temporal, en forma de movimientos rectos, curvos y figuras geométricas, guarda una relación simbólica con la vida espacial del Universo, es decir, con las relaciones y cambios espaciales de los cuerpos que componen el mundo [Weltkörper]141.

El arte de la danza degenera cuando se convierte en un juego de alardes técnicos acrobáticos, al preferir sin justificación alguna el movimiento vertical del salto frente a otros tipos de movimientos, y la danza "a solo" frente a la danza coral ${ }^{142}$. Por lo demás, Trahndorff observa que la danza en común tiene, en parte, una significación sensible, y en parte una significación "cosmética" (entendida, desde luego, en un sentido superior); en cualquier caso, no pertenece al arte libre ${ }^{143}$; la danza religiosa, en cambio, por encontrarse

139 Ibidem II 341-342. "So wie aber die Musik die überirdische Stimme ist, welche die Poesie begleiten soll und sich von ihr zur Selbständigkeit lösen, so tritt die Mimik und Schauspielkunst jetzt ein, um den Kampf des Lebens sichtbar darzustellen auf den Stufen desselben, wo der Schmerz und die Thorheit waltet; dagegen muss sie sich enthalten der Darstellung des Sieges und der Andacht, denn da diese eigentlich rein innere sind und ohne Verletzung ihrer Würde nicht als ein äusseres Mannichfaltiges, sondern als eine Einheit des Inneren erfasst werden müssen, in welcher die Individualität aufgehen soll, so können sie nicht Gegenstände mimischer Darstellung sein..."

140 Ibidem, II 293-294.

141 Ibidem II 293. E. v. Hartmann, quien valoró mucho las aportaciones de Trahndorff al análisis del mimo y la danza, se muestra, a pesar de todo, crítico con ellas. Considera que, aunque no cabe excluir que en las antiguas religiones naturales ciertas danzas y partes del culto tuviesen una relación simbólica con el curso de los planetas -como sucedía en el terreno arquitectónico con el zigurat-, lo cierto es que no se nos ha transmitido nada cierto sobre el uso simbólico de esas danzas, por lo que, prescindiendo de posibles casos excepcionales, la relación simbólica de los movimientos de la danza con los cambios de lugar que experimentan los cuerpos cósmicos en el Universo parece una suposición absolutamente injustificada: Cf. $O p$. cit., pág. 511.

142 Ibidem, II 302-305.

143 Ibidem, II 306-307. 
en íntimo conflicto con el principio religioso del Cristianismo, se vio muy pronto abocada a la extinción ${ }^{144}$.

La relación entre el mimo y la danza la describe Trahndorff de manera poco clara, diciendo que es equiparable a la relación que guarda la plástica con la arquitectura o la jardinería ${ }^{145}$, o a la relación de la poesía con la música146, aunque lo más acertado sería, quizá, compararla con la relación existente entre pintura y plástica. También señala que, entre los antiguos, el arte que seguía a la arquitectura y plástica en perfección era la danza, si bien no se dieron entre ellos condiciones óptimas para el desarrollo del mimo, como lo demuestra el uso constante de las máscaras ${ }^{147}$.

\section{2.- La unión de las artes}

Trahndorff plantea la idea de una posible unificación de las artes en el marco de una "obra de arte total" [Gesamtkunstwerk]. Esta unión es, en realidad, la meta última de todas las artes, que, impulsadas por la vida interna que las anima, tienden a constituir una totalidad orgánica ${ }^{148}$. El impulso unificador puede partir bien de las artes "plásticas" del reposo, bien de las artes "ético-teleológicas" del movimiento. En el primer caso la unión de la escultura y la pintura, crea estatuas policromadas, o figuras de cera; pero con ello se mezclan dos ámbitos que deberían permanecer separados, ya que "si la estatua ha de asumir la vida de los colores, debe asumir al mismo tiempo otras formas de manifestación de la vida", como el movimiento, y al no hacerlo, resalta demasiado su carencia de vida, mostrándose como algo apagado y muerto, es decir, como un cadáver ${ }^{149}$. Si se intenta evitar esta impresión repelente mediante los llamados "tableaux vivants", se fracasa de nuevo en la unión de las artes, pues en este caso se toman, efectivamente, individuos vivos, pero se suprime otra vez la expresión más determinada de su vida, el movimiento ${ }^{150}$. Por ello, Trahndorff plantea como posible obra de arte total el panorama [Panorama], esto es, pinturas paisajísticas circulares que servirían como marco para la vida que en ellas se representa, y que constituirían

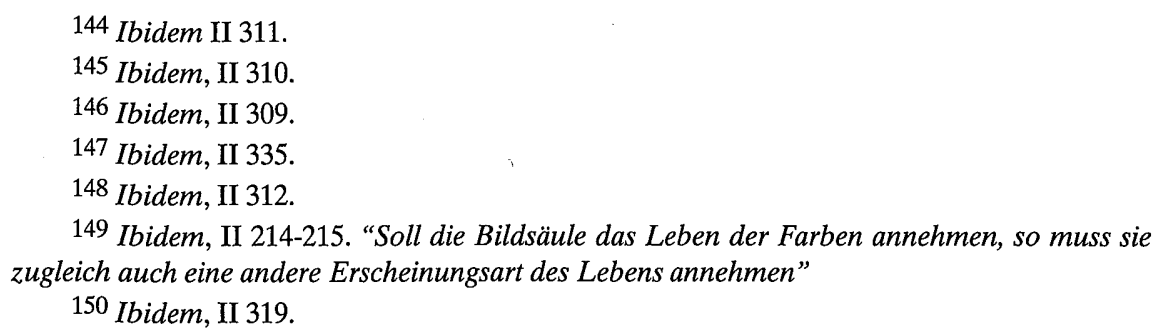


la "obra de arte total" desde el punto de vista del arte plástico ${ }^{151}$. Sin embargo, el mismo Trahndorff se ve obligado a reconocer que el panorama no resuelve tampoco los problemas de detención de la vida denunciados en los casos anteriores, y señala que aun el panorama más perfecto, "rodearía al contemplador como un mundo carente de vida, en el que él mismo terminaría por ver angustiosamente detenida su vida, como si se viese atrapado en la imagen de una vitalidad detenida en formas muertas. "152.

Así pues, Trahndorff -todavía muy alejado de los logros de la cinematografía a la hora de representar la vida y el movimiento- se ve reducido a postular una única obra de arte total verdaderamente capaz de abarcar todas las demás artes: la ópera, aunque no le dedica una explicación suficientemente detallada -carencia que, por lo demás, comparte con el resto de los estetas sistemáticos de su tiempo-153. Se limita a decirnos que la ópera está animada por la tendencia fundamental que subyace a todo arte, a saber: transfigurar la existencia, proyectándola en una apariencia estética que, a modo de "espejo mágico" [Zauberspiegel], logra ofrecernos una imagen total de la vida, en la que -como sucede con cualquier representación dramática de calidad-, el artista nos muestra "una imagen futura de la Humanidad ennoblecida por el arte"154.

Manuel Pérez CoRneJo

I. E. S. Matemático Puig Adam

Getafe (Madrid)

151 Ibidem II 316-320.

152 Ibidem. II 322. “...ein Panorama ganz so angeführt, sie es von uns entwickelt wurde, den Schauenden mit einer leblosen Welt umfassen würde, in welcher er ängstlich, wie befangen in dem Bilde eines erloschenen Lebens bei festgewordenen Formen, erwarten müsste, ebenfalls mit zu erstarren."

153 Ibidem, II 315-316.

154 Ibidem, II 321. "... ein Bild von der Zukunft der durch die Kunst veredelten Menschheit zeigen will." 